\title{
Preferences for Indoor Environmental and Social Comfort of Outpatient Staff during the COVID-19 Pandemic, an Explanatory Study
}

\author{
AnneMarie Eijkelenboom *(D), Marco A. Ortiz and Philomena M. Bluyssen (D) \\ Faculty of Architecture and the Built Environment, Delft University of Technology, \\ 2628BL Delft, The Netherlands; m.a.ortizsanchez@tudelft.nl (M.A.O.); P.M.Bluyssen@tudelft.nl (P.M.B.) \\ * Correspondence: a.m.eijkelenboom@tudelft.nl
}

Citation: Eijkelenboom, A.; Ortiz, M.A.; Bluyssen, P.M. Preferences for Indoor Environmental and Social Comfort of Outpatient Staff during the COVID-19 Pandemic, an Explanatory Study. Int. J. Environ. Res Public Health 2021, 18, 7353. https:// doi.org/10.3390/ijerph18147353

Academic Editors:

Derek Clements-Croome,

Valerie Mace, Youmna Dmour and Ankita Dwivedi

Received: 4 June 2021

Accepted: 6 July 2021

Published: 9 July 2021

Publisher's Note: MDPI stays neutra with regard to jurisdictional claims in published maps and institutional affiliations.

Copyright: (c) 2021 by the authors. Licensee MDPI, Basel, Switzerland. This article is an open access article distributed under the terms and conditions of the Creative Commons Attribution (CC BY) license (https:// creativecommons.org/licenses/by/ $4.0 /)$.

\begin{abstract}
While the pressure on hospital workers keeps growing, they are generally more dissatisfied with their comfort than other occupants in hospitals or offices. To better understand the comfort of outpatient workers in hospitals, clusters for preferences and perceptions of the indoor environmental quality (IEQ) and social comfort were identified in a previous study before the outbreak of the coronavirus disease 2019 (COVID-19) pandemic. This qualitative study explains the outpatient workers' main preferences for comfort during the COVID-19 pandemic. Semi-structured interviews and photo-elicitation were used. Contextual changes due to the COVID-19 pandemic were included. The questions in the interviews were based on the characteristics of the profiles, corresponding with the clusters. The data were analyzed with content analysis according to the steps defined by Gioia. Seventeen outpatient workers who had been part of the previous study participated. For some outpatient workers differentiation of preferences was illogical due to interrelations and equal importance of the comfort aspects. The main changes in perceptions of comfort due to the pandemic were worries about the indoor air quality and impoverished interaction. Because the occupants' preferences for comfort can change over time, it was suggested that further development of occupant profiles needs to accommodate changes.
\end{abstract}

Keywords: hospitals; COVID-19; preferences; outpatient areas; multisensory; IEQ; semi-structured interviews; design; health; hospital staff

\section{Introduction}

As the pressure on hospital workers grows due to the increasing demand for healthcare [1], in the Netherlands almost half of these hospital workers experienced high work pressure in 2019 [2]. Stress can have a negative influence on work satisfaction, performance, and healthcare staff turnover [3-5]. One of the factors that can influence stress at work is the physical environment [6]. For example, previous studies showed that work dissatisfaction and hospital workers' turnover were positively related to dissatisfaction with noise [7] and the length of daylight exposure [8].

The study of comfort, specifically that of hospital workers, is important because previous studies identified a tendency of higher dissatisfaction of hospital workers with the comfort compared to patients [9-11]. Other studies have shown that hospital staff are also less satisfied with their comfort and suffer more from building-related symptoms than occupants in office buildings $[12,13]$. To improve the health and comfort of the hospital workers it is important to better understand their needs and preferences.

\subsection{Background}

It has been suggested by several authors that IEQ as well as social comfort aspects are important to understand health and comfort [14-16]. Privacy and interaction have been included in previous studies. For example, nurses that moved from open bay wards to a 
ward with $100 \%$ single patient rooms, missed the informal interaction with colleagues in the new wards [17]. Also, the exchange of medical information was better in open wards, that comprised of 36 beds without separation walls, than in bay wards with walls between 4-6 beds [18]. Another example is the relation of the type of communication (case related or comforting) with room types in an emergency department [19].

As hospitals are complex buildings that accommodate a large variety of activities, the hospital workers' needs for comfort can vary between hospital departments [20,21]. Therefore, it is important to gain insights into comfort in specific hospital areas, such as outpatient areas. Because outpatient areas have been understudied, a survey on the comfort and health of hospital workers in these areas was performed in the spring of 2019 [22]. In these areas hospital workers consult, diagnose, and treat patients who do not stay overnight in the hospital. Data from 556 outpatient workers were collected with a questionnaire and data from 107 rooms, the building services, and locations of six hospitals were collected with a building inspection. The questionnaire included the occupants' assessment of IEQ factors, (indoor air quality, thermal comfort, lighting quality, and acoustics) and social comfort aspects (privacy, distraction, interaction). The study identified that the satisfaction with IEQ and social comfort varied, depending on the room types where the outpatient workers worked most frequently. For example, those who worked more frequently in a consultation room were more satisfied with privacy than those who worked in offices.

Questions on the preferences that were closely related to the questions on the perception of IEQ and social comfort were also included, in order to identify differences in needs between individual occupants. Because comfort can vary between individuals, due to differences in reaction and sensitivity to building characteristics, profiles of outpatient workers were produced to justify the variation in comfort between individuals [23]. The profiles were produced with) Two-Step Cluster analysis in IBM SPSS Statistics 25. This is a segmentation method that is suitable to identify groups with similar needs [24]. Two sets of clusters were produced: one set including satisfaction and preferences for IEQ and another one including satisfaction and preferences for social comfort [25]. In both sets of clusters, the preferences had higher importance than dissatisfaction.

The strong differentiation of the preferences between the clusters brought in the question of how occupants differentiate their preferences. Previous studies identified that the preferences of hospital workers were associated with personal and work-related aspects, such as gender, age, working hours [26], working years, and the function of areas [27]. However, these studies did not explain how the occupants perceived their preferences and comfort. Studies on preferences for thermal comfort in offices [28,29] and housing [30,31] showed that needs, behavioural strategies, and control of equipment were interrelated with the specific context. Therefore, it is important to explain the preferences of occupants within their context.

However, the context of outpatient areas may have changed because of the outbreak and worldwide spread of the SARS-CoV-2 virus, leading to the coronavirus disease 2019 (COVID-19) pandemic in the spring of 2020 [32]. Previous studies showed that the outbreak of a serious infectious disease may increase work stress and affect the health of hospital workers [33-36]. As rapid changes in care processes may influence the perception of comfort, assessing the hospital environment is needed when changes occur [37].

\subsection{Objective}

Because of limited information on the hospital workers' preferences for comfort, this study aims to explain the differences in preferences of outpatient workers that were identified in the clusters of the 2019 survey. This study provides insights into the comfort experience of outpatient workers during the COVID-19 pandemic and changes of their preferences during the pandemic.

The present study is part of a larger research project that aims to gain a better understanding of the health and comfort of outpatient workers. The study acts as a follow-up to 
the survey that was performed with outpatient workers of three hospital organizations in the Netherlands before the COVID-19 pandemic started [22,25] (Figure 1).

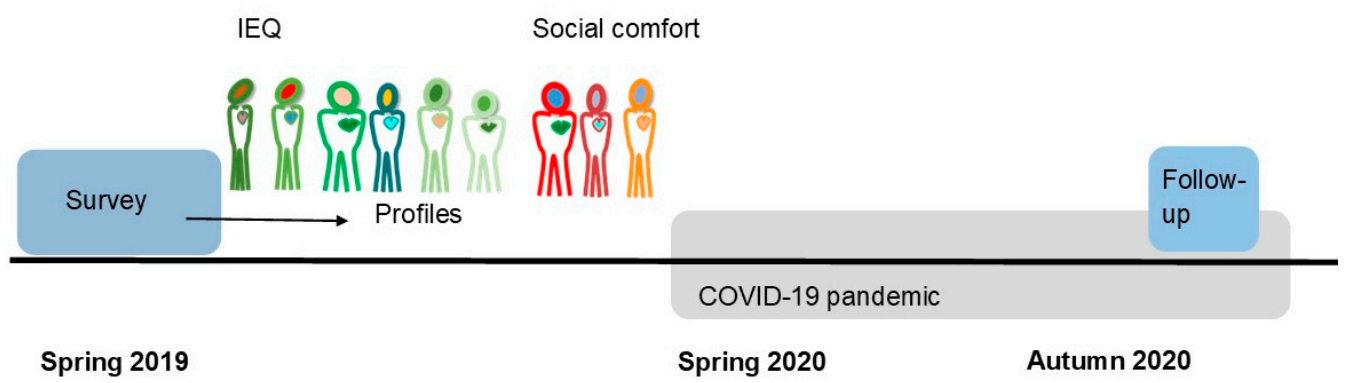

Figure 1. Timeline profiles.

\section{Materials and Methods}

\subsection{Study Design}

A qualitative approach was selected because of the unknown context due to the COVID-19 pandemic and limited information on the experience of comfort preferences. A qualitative approach allows to study possible changes over time and to listen to the reallife experiences of occupants in the built environment [38]. Qualitative data are suitable to refine and explain the results of the quantitative analysis [39] that was used to produce the clusters and their profiles. This explanatory study was based on a pragmatic worldview, considering both the physical world and human experience [40].

The study design combined photography and semi-structured interviews to gain an in-depth understanding of the preferences of the outpatient workers. The critical appraisal skills programme checklist for qualitative research was used for the study design [41].

The participants were selected out of the respondents who participated in the previous survey on comfort and health [25] and had shared their e-mail addresses to participate in a follow-up study. The study intended to include outpatient workers with different functions from all three hospital organizations and all IEQ and social clusters, to gain a representative overview. Participants who were relocated to a location that was not part of the survey or who could not work at one of the six locations due to illness, were not included.

Invitations and reminders were sent by e-mail in October 2020. The outpatient workers who accepted the invitation to participate received a proposal for dates and times and an instruction sheet to take the photographs (Figure 2). In the instruction sheet, it was explained that the photographs were needed to provide insights into the importance of IEQ and social comfort aspects during the interview. It was instructed that other rooms could be photographed to explain the importance of comfort aspects. IEQ was defined as: "aspects from the indoor environment: ventilation, temperature, noise and light". Social comfort was defined as: "contact with others, distraction, safety, privacy, crowding". To protect the privacy of patients and staff, instructions were given to exclude persons and personal information from the images.

Photographs were used because images support communication, as shown in studies on the perception of building characteristics [42]. Images in research have been used and tested before and support the narrative of real-life experiences [43]. For example, in a study that explored the patients' experience when they were lying in a bed, patients took photographs in advance of the semi-structured interviews [44]. It was concluded that visual material cannot only illustrate visual but also auditory or other sensory qualities of the physical environment during the interviews. A practical reason to use photographs was to gain insights into the building characteristics while avoiding infection risk by the interviewer by visiting the hospitals. It should be noted that the interviewer had systematically inspected all hospital buildings before the pandemic started [25]. 


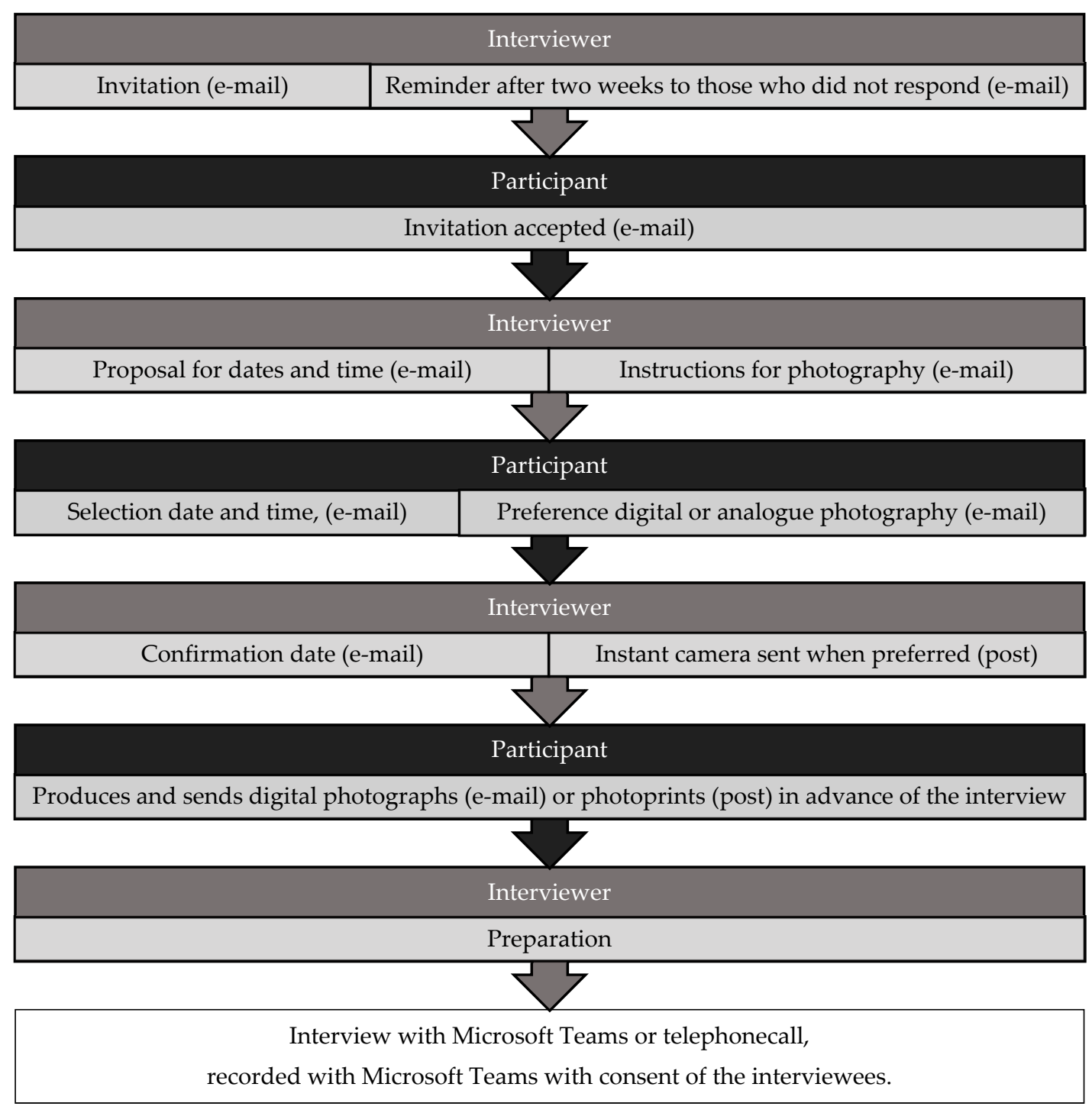

Figure 2. Procedure.

The semi-structured interviews were conducted via video calls or telephone calls, depending on the participant's preference and technological possibilities. All interviews were audiotaped with Microsoft Teams with the consent of the participants. Semi-structured interviews were used because these enable to explore perceptions of the respondents, while they allow for differences in education, experience, and personal background between individuals [45]. The structure of the interviews enabled follow-up questions to be asked [46]. To reduce the potential bias of the researcher, the interviews started with an introduction and general questions about work. In the introduction it was explained that there was no right or wrong answer. The questions were phrased neutrally, and leading questions were avoided.

The interview guide comprised of newly developed questions, that were discussed and tested in a pilot. The interviews consisted of five main topics: work-related aspects, changes due to the COVID-19 pandemic, preferences for IEQ, preferences for social comfort, and ranking of preferences (Table 1). The subtopics were aspects that were differentiated by the profiles of the outpatient workers in the previous survey on comfort and health [25]. For example, the number of persons in the room was a subtopic because it varied between the clusters. A comparison with the data from the survey was done to check whether the room type, department, or location of the participants had been changed. The subtopic 'Logic to differentiate preferences' was added to gain insight into whether the participants 
experience clear differences between their preferences. The ranking was performed separately for comfort with IEQ-aspects and social comfort. The aspects that were identified in the previous survey as most important were used for the ranking. The IEQ-aspects were control of ventilation, sufficient fresh air, control of temperature, not too cold or hot, sufficient daylight, no annoyance by noise. For social comfort, the aspects were contact with patients and colleagues, a safe workplace, sufficient patient privacy, no distraction from noise. The structure of the interview was tested in a pilot interview with an outpatient worker from a similar hospital organization (teaching hospital). The pilot provided insights into the structure of the interview and the use of photographs. Consequently, the researcher piloted two interviews with two outpatient workers from similar hospital organizations.

Table 1. Topic guide semi-structured interviews.

\begin{tabular}{ccc}
\hline Main Topic & Subtopics & Shared Documents \\
\hline Introduction & $\begin{array}{c}\text { Room, room type, number of } \\
\text { persons in room, function, job } \\
\text { tasks, department, location }\end{array}$ & \\
\hline Changes due to the pandemic & $\begin{array}{c}\text { Activities, work pressure, } \\
\text { physical changes, other }\end{array}$ & Photographs \\
\hline Preferences IEQ & $\begin{array}{c}\text { Thermal, ventilation, } \\
\text { lighting, noise }\end{array}$ & Photographs \\
\hline Preferences social comfort & $\begin{array}{c}\text { Contact, safety, privacy, } \\
\text { distraction }\end{array}$ & List of ranking IEQ and \\
social comfort
\end{tabular}

\subsection{Ethical Approval}

The Ethics committee of the Delft University of Technology approved the study design on 5 October 2018. Data security was assessed by a data manager of the university. The data were stored on a secured server. Participation of the hospital organizations and participants was voluntary. Participants could participate only after their approval of informed consent. The letter of consent and procedure were discussed and approved with the project leader of each participating hospital organization in advance. If the participants had shared their e-mail address in the previous survey, it was separated from the dataset and secured in a separate document. Comparison of the individuals' data between the survey and this follow-up study was enabled by a unique number that was assigned to each participant. To respect the privacy of the participants, persons are not traceable from the results presented.

\subsection{Data Analysis}

Data analysis was performed during the two phases, and in the steps shown in Figure 3. In the first phase inductive analysis was performed to structure the changes due to the COVID-19 pandemic. An inductive approach was used, because of the unknown context. In the second phase deductive analysis was performed to structure the main occupants' preferences and enable comparison with the data of the previous survey. Microsoft Excel was used for the data codes. 


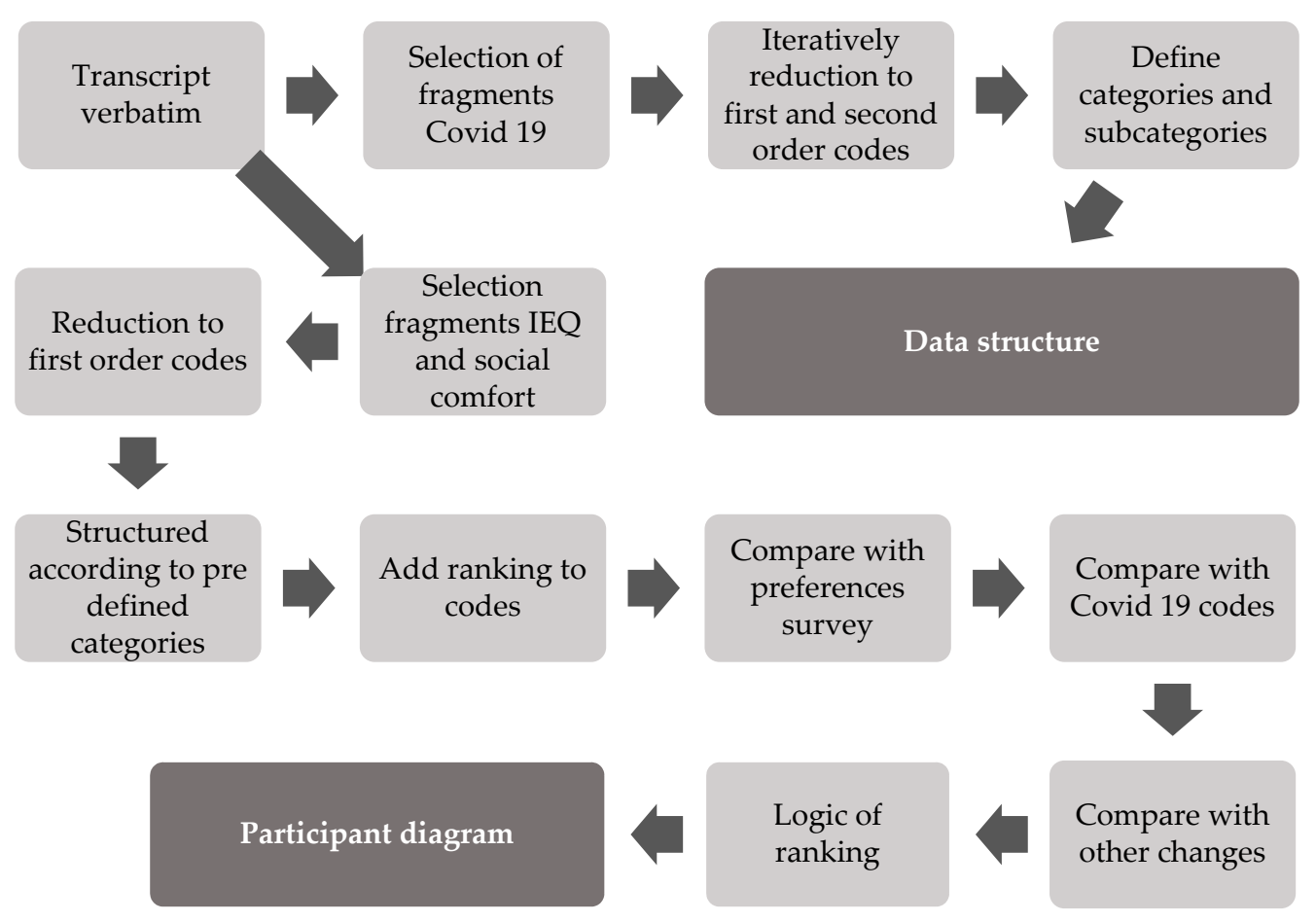

Figure 3. Steps for data analysis.

The interviews were transcribed verbatim and read to prepare for analysis. The average duration of the interviews was $31 \mathrm{~min}$, varying from 14 to $56 \mathrm{~min}$, depending on the participants' time and experience. To structure and summarize the changes due to the COVID-19 pandemic, content analysis was used, according to the steps of Gioia et al. [47]. Meaningful text segments that explicitly referred to the COVID-19 pandemic were systematically selected, condensed, and paraphrased into first-order codes, that were closely related to the wording of the participants. Subsequently, these first-order codes were grouped into second-order codes, iteratively formed by the main investigator. The second-order codes were translated from Dutch to English. All first- and second-order codes of two participants were checked by another researcher, a native English speaker, the second order codes were recoded, and checked until consensus was achieved. Differences were discussed to improve the accuracy of the codes. The second-order codes were grouped into subcategories and categories to form a data structure that was discussed with two other researchers. Subsequently, the second-order codes were assigned independently into subcategories and categories in a digital workshop by seven other researchers to achieve intercoder agreement. Three of the 53 codes were placed in a different subcategory in the digital workshop compared to the initial data structure. Furthermore, it was suggested to add one extra subcategory, and the names of the categories and subcategories were discussed. These results were used to define the final data structure.

To investigate how the comfort preferences changed, the participants' preferences from the survey [25] were compared with their preferences from the interviews. Therefore, all relevant text segments, that referred to the ranked IEQ and social comfort aspects were systematically selected. These fragments were condensed and paraphrased in first-order codes and categorized according to predefined categories per participant. This was done for IEQ and social comfort separately. The IEQ-categories were the four IEQ aspects [23], i.e., indoor air quality, thermal comfort, visual quality, acoustics, and logic of ranking IEQ. The social comfort categories were the four most important social comfort aspects that were determined in the survey [25], i.e., contact with colleagues and patients, a safe workplace, sufficient patient privacy, no distraction from noise, and logic of ranking social comfort. The codes were checked and recoded iteratively by two researchers. Then the codes and 
ranking were compared with the individuals' preferences of the survey, the changes due to the pandemic, other changes, and the logic of ranking.

To illustrate the IEQ and social comfort experiences [48], quotations by the participants from transcripts verbatim that were detailed and representative, were selected [49]. To justify the unique experiences of the participants [50], gap words and some repetitions of thoughts were kept in the quotations. The quotations were translated back and forward by the authors (native Dutch and English, see Appendix A for the quotations).

\section{Results}

\subsection{Participants}

The interviews were performed in the last week of October and the first half of November in 2020. 130 invitations $(38+45+47)$ respectively to organizations $\mathrm{A}, \mathrm{B}$, and $\mathrm{C}$ were sent, $17(5+7+5)$ interviews were included in the analysis, as seen in Figure 4 . The main reason for refusing to participate was work pressure. One audio recording was damaged, therefore that participant was excluded from the analysis.
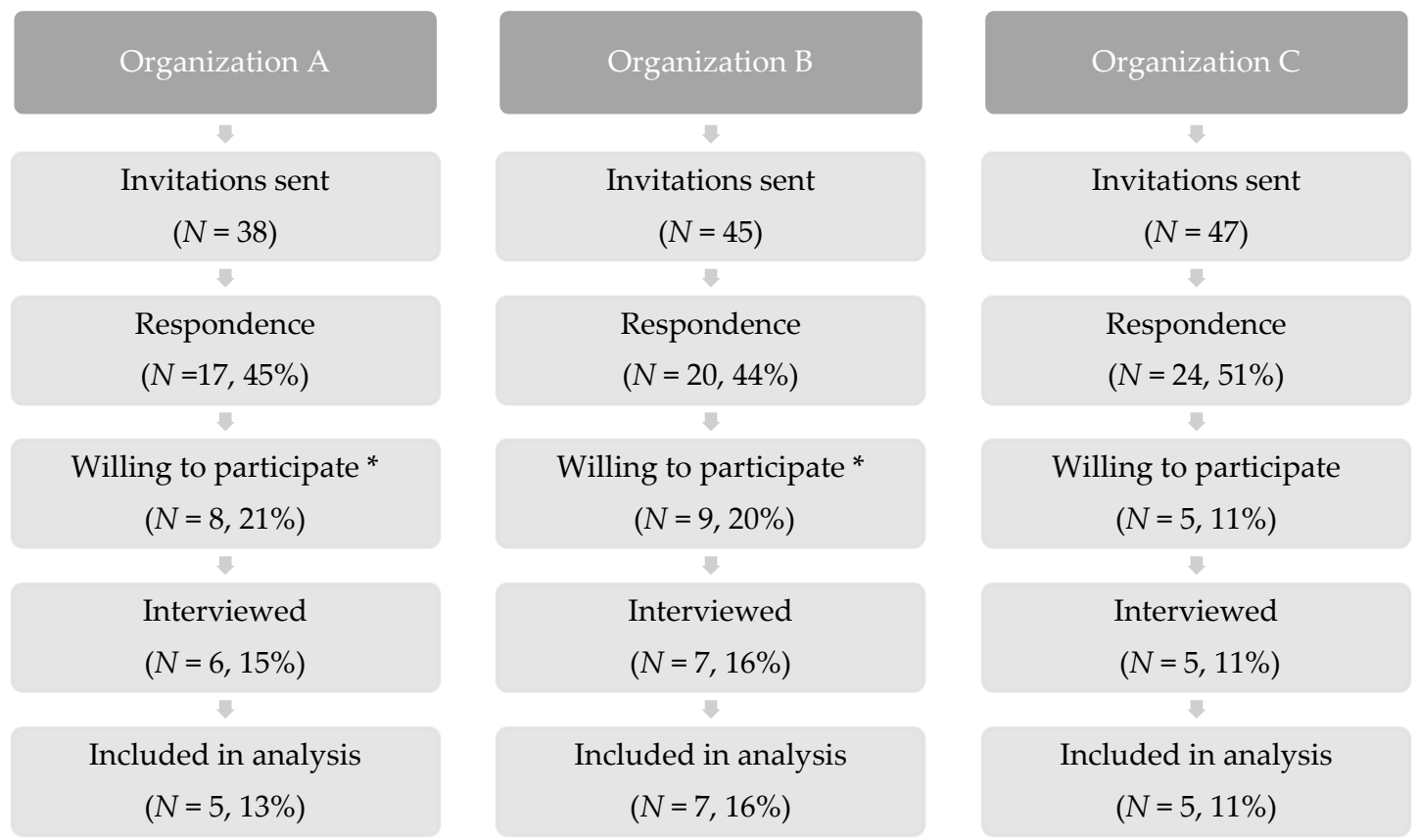

Figure 4. Flow diagram of recruitment. ${ }^{*}$ inclusive participants that were not within the inclusion criteria or canceled.

The participants, who consisted of 16 women and one man, represented all IEQ and social comfort clusters and belonged to all the hospital organizations that participated in the survey. The participants worked in consultation rooms, treatment rooms, offices, or at reception desks; thirteen of them worked in more than one room type, see Figure 5. For example, three interviewees worked at reception desks and consultation rooms.

Nine participants regarded the same IEQ-aspect as most important, as selected in the in the 2019 survey (Table 2). For example, one participant regarded sufficient fresh air as most important in the autumn of 2020, and sufficient fresh air and not too cold or hot important in the spring of 2019. Some found the ranking of IEQ aspects from most important to least important logical, while others did not. No annoyance with noise or sufficient daylight were for some the most important aspects, while the other aspects were equally less important. The main preferences for indoor air quality and thermal quality did not vary, except for one participant who did not answer the question on IEQ-preferences in the survey of 2019. The main preferences for daylight and noise varied. 


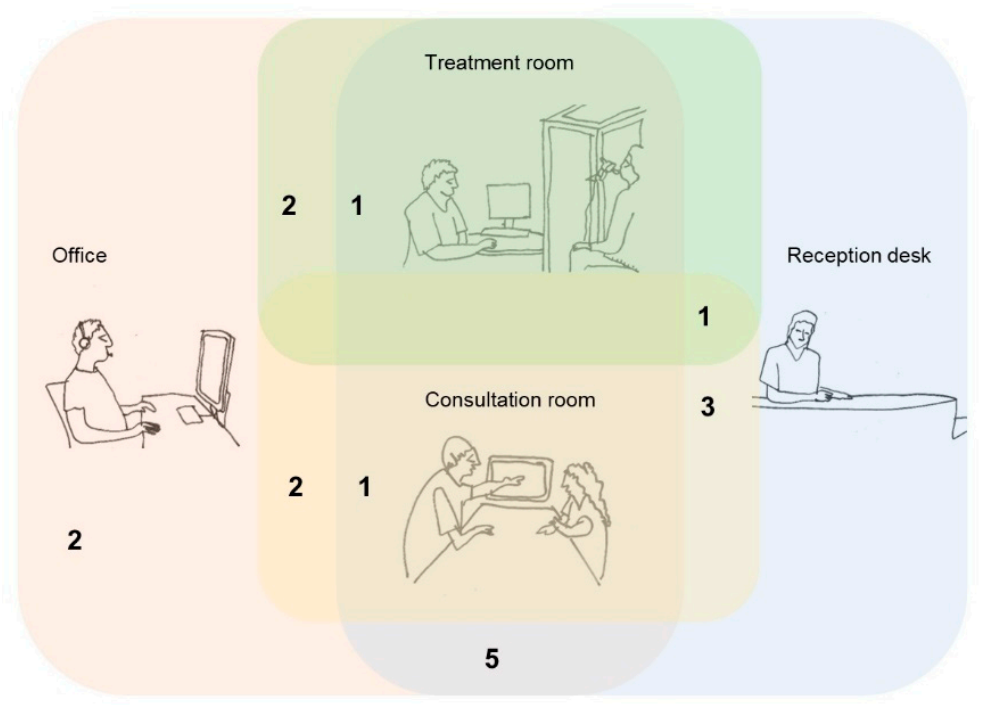

Figure 5. Overlap of workplaces of the participants.

Table 2. Main preference in 2020 compared to 2019.

\begin{tabular}{cccc}
\hline & Most Important Aspect & $\mathbf{2 0 2 0}$ & Same Preference in 2019 \\
\hline $\begin{array}{c}\text { Indoor } \\
\text { Environmental } \\
\text { Quality (IEQ) IEQ }\end{array}$ & Sufficient fresh air & N & N \\
\hline & Control of ventilation & 2 & 1 \\
\hline & Not too cold or hot & 3 & 2 \\
\hline & Control of temperature & 1 & $2{ }^{*}$ \\
\hline & Sufficient daylight & 5 & 1 \\
\hline Total IEQ & No annoyance by noise & 5 & 1 \\
\hline Social comfort & Sufficient contact & 17 & 9 \\
\hline & No distraction by noise & 3 & 7 \\
\hline Total Social comfort & Privacy for patients & 4 & 1 \\
\hline${ }^{*}$ Incomplete answer of participant in 2019 excluded. & 3 & 0 \\
\hline & Safe workplace & 17 & 10 \\
\hline
\end{tabular}

* Incomplete answer of participant in 2019 excluded.

Ten outpatient workers regarded the same social comfort aspect as most important in both 2019 and 2020. Some outpatient workers found the ranking of social comfort aspects logical, while others perceived an overlap between contact with colleagues and patients and a safe workplace. The importance of social comfort aspects could also depend on a situation or activity. The importance of maintaining the privacy of patients was considered a question of conscience. The main preference for sufficient contact did not vary, while the other preferences did.

\subsection{Changes Due to the Coronavirus Disease 2019 (COVID-19) Pandemic}

The data structure generated insights into organizational aspects, work-related aspects, physical adaptations, and the experience of changes, that were identified by the participants (Table 3). The structure was used to understand the preferences for indoor environmental quality and social comfort during the COVID-19 pandemic. First, the organizational aspects, 
work-related aspects, and physical adaptations were summarized, to describe the context. Then the experiences, especially related to the indoor environment and social comfort, are explained. See Appendix B, Table A1 for all second-order codes.

Table 3. Data structure of the changes related to the coronavirus disease 2019 (COVID-19) pandemic.

\begin{tabular}{|c|c|c|}
\hline Category & Subcategory & Example \\
\hline \multirow[t]{2}{*}{ Organizational adaptations } & Capacity & $\begin{array}{l}\text { Reduction capacity during first } \\
\text { wave of the pandemic }\end{array}$ \\
\hline & $\begin{array}{l}\text { Number of persons in hospital } \\
\text { building }\end{array}$ & Working partly from home \\
\hline \multirow[t]{3}{*}{ Adaptations work methods } & Corona care & Perform corona tests in triage tent \\
\hline & Digital care & Prepare digital consultations \\
\hline & Face-to-face care & $\begin{array}{l}\text { Physical examination when } \\
\text { urgent }\end{array}$ \\
\hline \multirow[t]{2}{*}{ Physical adaptations } & Room & $\begin{array}{l}\text { Stanchions in front of reception } \\
\text { desk }\end{array}$ \\
\hline & Protective clothing & Use of facial mask \\
\hline \multirow[t]{4}{*}{ Personal experiences } & Work-pressure & Increased work pressure \\
\hline & Satisfaction with work & Annoyed by extra administration \\
\hline & $\begin{array}{l}\text { Indoor Environmental Quality } \\
\text { (IEQ) }\end{array}$ & Missing control of ventilation \\
\hline & Social comfort & Missing face-to-face contact \\
\hline
\end{tabular}

\subsubsection{Context}

In March/April 2020, during the first wave of the pandemic, the capacity of outpatient care had been reduced for most participants. At the time of the interviews, most participants regarded the capacity of outpatient care as normal. The number of patients, relatives, and staff in the hospital buildings was perceived lower than before the COVID-19 pandemic. To limit the number of persons in the hospital buildings, outpatient care had shifted from face-to-face care to digital care. Face-to-face consultations were only performed when necessary or when preferred by patients, also depending on the department. For example, one outpatient worker in an oncology department explained that patients were invited to face-to-face consultations when they were told that they were seriously ill. Diagnostic treatment was performed at the hospital buildings.

The adaptation of work methods resulted in annoyance with extra administration and worries about infection and patient care. Half of the participants perceived increased work pressure at the time of the interviews, while the others did not. Some reception workers had perceived increased work pressure mainly when the COVID-19 pandemic started. Work pressure increased also because of limited staff and prolonged sick leave, not directly related to the COVID-19 pandemic. Positive experiences were easily adjusted to new work methods and satisfaction with the hospital organizations' diligence.

To support social distancing between persons, some adaptations were executed in the reception areas and adjacent waiting rooms. For example, cupboards were replaced; and stanchions in front of the reception desk were placed (Figure 6). Also, the number of chairs in waiting rooms was reduced, or splash guards were provided between the chairs. Other protective measures were the use of a facial shield or facial mask and a transparent splash guard, placed at reception desks (Figure 6). Both photographs are taken by participants. 


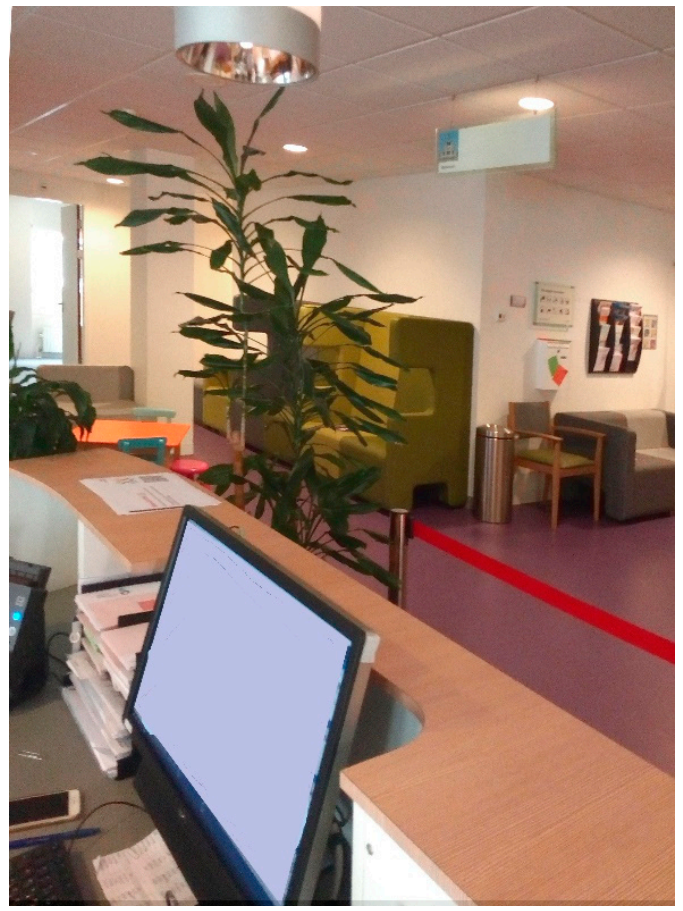

(a)

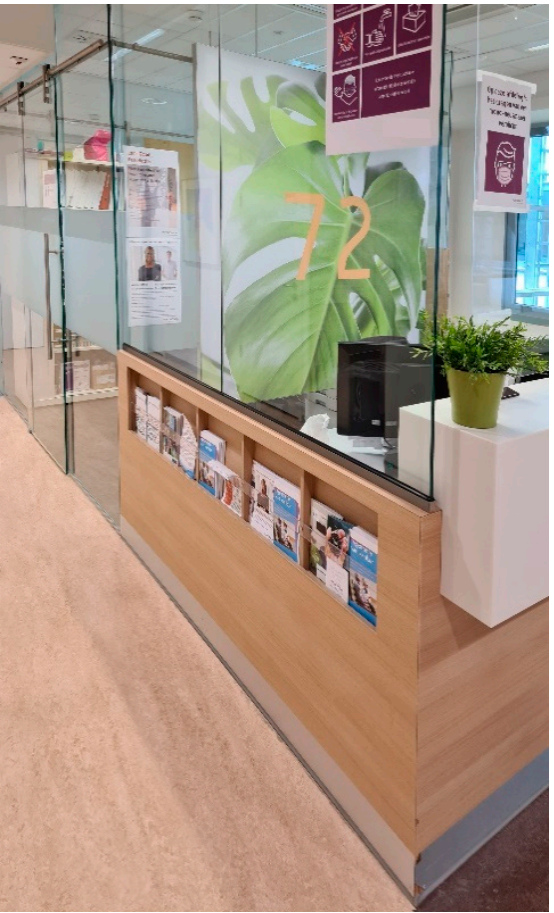

(b)

Figure 6. (a) Stanchions in front of reception desk; (b) splash guard installed at reception desk.

\subsubsection{Indoor Environmental Quality}

The perception of the indoor air quality, thermal comfort, and noise was influenced by the COVID-19 pandemic.

The outpatient workers explained that they preferred to have natural ventilation by opening a window or the door to the corridor, to reduce the risk of infection (For example, quotation 1 in Appendix A, "And I find it annoying too now ... "). An adaptive strategy was to open the door to the corridor when the outpatient workers who were in a room without a façade window were dissatisfied with the supply of mechanically ventilated air. This was only possible when it did not affect the privacy of the patients. Another strategy was to open the façade window for natural ventilation. However, this could affect thermal comfort, which might vary between outpatient workers who worked in the same room. When the window was open, it could be too cold for some workers, especially for those in uniform (with bare arms), while it was not too cold for others. An outpatient worker explained that they had clear appointments about control of natural ventilation to achieve a balance of thermal comfort and natural ventilation since the pandemic (quotation 2 in Appendix A, "I like a little bit of air ... ").

Also, the speech intelligibility of patients was reduced due to the splash guards between the patient and outpatient workers at the reception desk. The noises from colleagues at the back of the reception area were louder because of the splash guards, while the voice from the patients sounded lower. The facial masks increased difficulties with speech intelligibility (quotation 3 in Appendix A, "If it weren't any noise annoyances").

Furthermore, recent changes in preferences that were not explicitly associated with the COVID-19 pandemic, were experienced. This occurred for noise and daylight. For example, one participant who worked mainly in rooms without a façade window missed daylight more than she used to do. Dry eyes and concentration problems were associated with a lack of daylight. The outpatient worker adapted her behaviour to receive daylight, by going out for a walk during lunchtime and working in rooms with a window when possible (quotation 4 in Appendix A, "I have noticed that I used to suffer less with that ... "). These strategies were also explained by some other interviewees, who worked generally in rooms without a façade window. 


\subsubsection{Social Comfort}

The outpatient workers also experienced changes in contact with colleagues and patients, privacy of patients and safety, due to the COVID-19 pandemic.

Some felt less energized because of the reduced face-to-face contact with patients and increased administrational work. The perception of losing information from the patients occurred because of the limited face-to-face contact. For example, one outpatient worker explained that she could not explain doubts to patients anymore after consultation with the physician (quotation 5 in Appendix A, "When you ask ... "). Another outpatient worker explained that she was worried about missing details and could give less attention to the patients due to the limited physical examination (quotation 6 in Appendix A, "And yes, the physical check-up is something you miss ..." ).

A shorter physical distance, which was not allowed due to infection risk, was regarded as advantageous to support the patients' privacy by speaking softly. The privacy of patients at the reception desk also worsened due to the splash guards and facial masks. For example, the outpatient workers had to ask for personal information, such as the birth date and the name of the general practitioner, while others were in the waiting room. The patients had to talk louder because of the splash guards (quotation 7 in Appendix A, "You discuss everything..." ").

Some outpatient workers perceived difficulties through increased aggression. Patients were impatient or angry, for example because of the obligation to wear a facial mask. The opposite was also experienced, because the number of visiting patients had decreased, and aggression during telephone calls was less annoying.

\section{Discussion}

The qualitative data allow for a vivid explanation of the context [38] and changes due to the COVID-19 pandemic. Contextual changes were studied to explain the experience and importance of comfort aspects. Because the participants in this study had been involved in the cluster study [25], a comparison of the preferences was possible. This is presented and discussed in the following section.

\subsection{Explanation of the IEQ Clusters}

Figure 7 shows the preferences for IEQ aspects per cluster, that were found in the survey before the pandemic started, and the preferences during the pandemic. The circles represent the proportion of the outpatient workers who regarded an IEQ aspect important before the pandemic and the ranking of the outpatient workers during the pandemic. The area of the green circles represents the proportion of the cluster members for a main preference. The largest circles (e.g., cluster 1 control of ventilation) represent $100 \%$, the green dots represent $0 \%$ of the cluster members. The area of the purple circles represents the ranking of the preferences; large is most important (1, size 100\%), small is least important (6, dot). The size of the purple circles was calculated according to the following equation, with $v=$ the sum of ranking of the participants per cluster, $n=$ number of cluster members:

$$
100-\left(\left(\frac{v}{n}\right) \times\left(\frac{100}{5}\right)-\left(\frac{100}{5}\right)\right)
$$




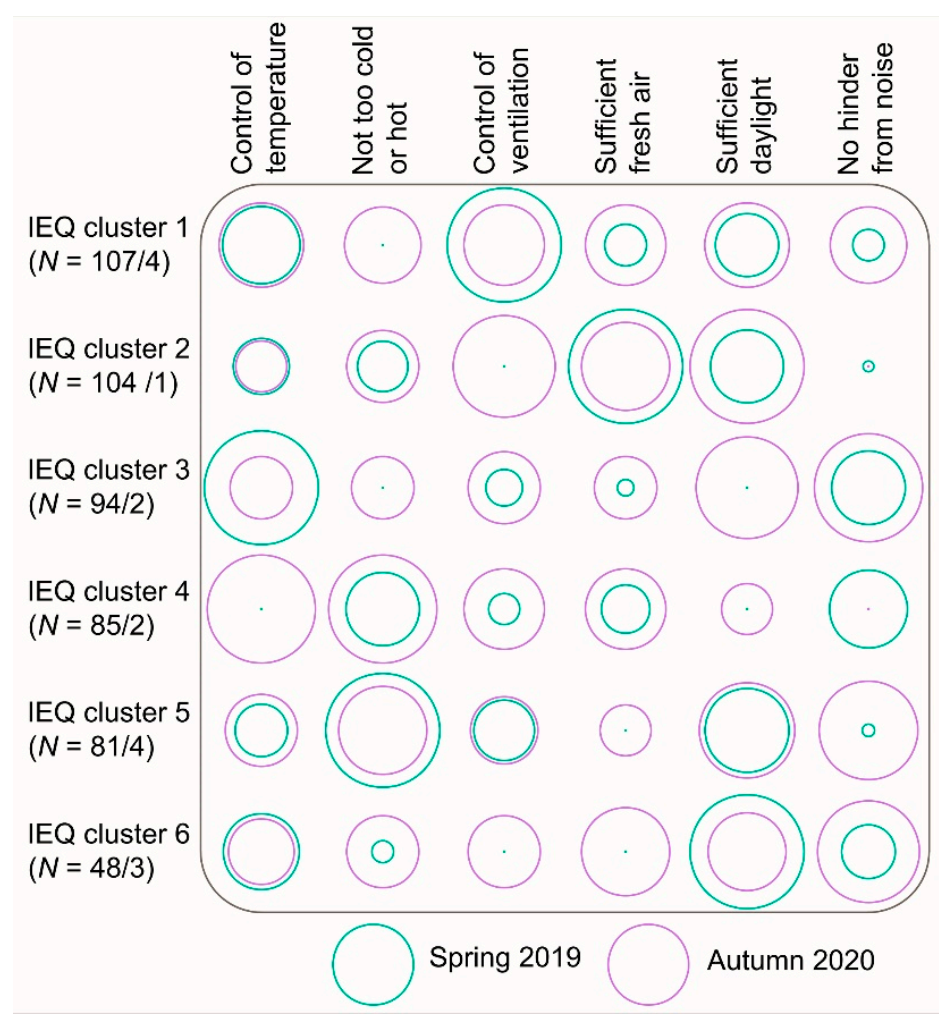

Figure 7. Proportion of preferences selected per IEQ cluster in 2019 and average rating of preferences in 2020 .

The number of cluster members from the survey of 2019 and interviews in 2020 are shown as follows: IEQ cluster $\times(\mathrm{N}=\mathrm{a} / \mathrm{b}): \times$ is the cluster number, $\mathrm{a}=$ number of cluster members of the study in 2019, b = number of cluster members of the study in 2020 .

The importance of some preferences had a limited variation between both data sets. For example, the proportion of outpatient workers in cluster 1 who found control of temperature important was intermediate $(46 \%)$, and ranking was intermediate $(3.3$, of six aspects with 1 for most important, 6 least for important). Other preferences differed; for example, none of the outpatient workers in cluster 1 selected not too cold or hot among the three most important aspects in the quantitative study $(0 \%)$, while it was ranked intermediately (3.8) in the qualitative follow-up study. The largest differences were not too hot or cold (cluster 1), control of temperature (cluster 4), control of ventilation (cluster 2), sufficient daylight (cluster 3), no annoyance by noise (cluster 5).

These differences suggest that the clusters that were mainly differentiated by the preferences could change due to contextual or personal changes. For example, one of the main contextual changes due to the COVID-19 pandemic was the reduced number of persons in the buildings and rooms. The IEQ-clusters mutually differed for those working in rooms with two to four persons and rooms with more than four persons. It was explained by the outpatient workers of cluster 4 and cluster 5 that the preferences of colleagues were one of the factors that influenced the control of temperature and ventilation.

The reason why the outpatient workers found IEQ aspects important, varied between the clusters. For example, in addition to concerns for infection with the SARS-CoV-2 virus, control of ventilation and sufficient fresh air were preferred because fresh air was experienced as enjoyable and attractive for those in clusters 2 and 6 . However, the outpatient workers in cluster 1 found control of ventilation and sufficient fresh air important because they were dissatisfied with the indoor air quality. Those in cluster 1 found thermal comfort important because they were mainly dissatisfied with the temperature variation, while it was important in cluster 4 because of draught. Thermal comfort was important for those in cluster 5 because they mainly experienced too cold temperatures even after 
adjusted clothing (e.g., cardigan on top of uniform). Daylight was preferred because of dissatisfaction with the absence of a façade window in cluster 1 , while some in clusters 4,5 , 6 did not need or expect a façade window. The view to the outside, which was associated with sufficient daylight, was missed (cluster 1) or enjoyed (cluster 2, 3, 6). The importance of noise was for those in clusters 1 and 6 mainly related to speech intelligibility of patients, which had decreased due to wearing of facial masks and splash guards, while outpatient workers in clusters 3 and 5 perceived stress due to annoyance by noise.

Based on the explanation of the data from the survey and interviews, it can be suggested that the needs of those in different IEQ clusters do not only vary in importance, but also due to differences in expectations and sensitivity. The clusters seem to be influential for contextual changes or personal changes, due to large differences, especially in clusters 2,3 , and 4 .

\subsection{Explanation of the Social Comfort Clusters}

Figure 8 shows the preferences for social comfort that were found in the survey before the pandemic started, and the preferences during the pandemic. The size of the circles represents the importance of a specific comfort aspect. The area of the green circles represents the proportion of the cluster members for a preference. The green dots represent $0 \%$ of the cluster members. The area of the purple circles represents the ranking of the preferences; large is most important $(1$, size $100 \%)$, small is least important $(4$, dot). The size of the purple circles was according to the following equation, with $v=$ the sum of ranking of the participants per cluster, $n=$ number of cluster members:

$$
100-\left(\left(\frac{v}{n}\right) \times\left(\frac{100}{3}\right)-\left(\frac{100}{3}\right)\right)
$$

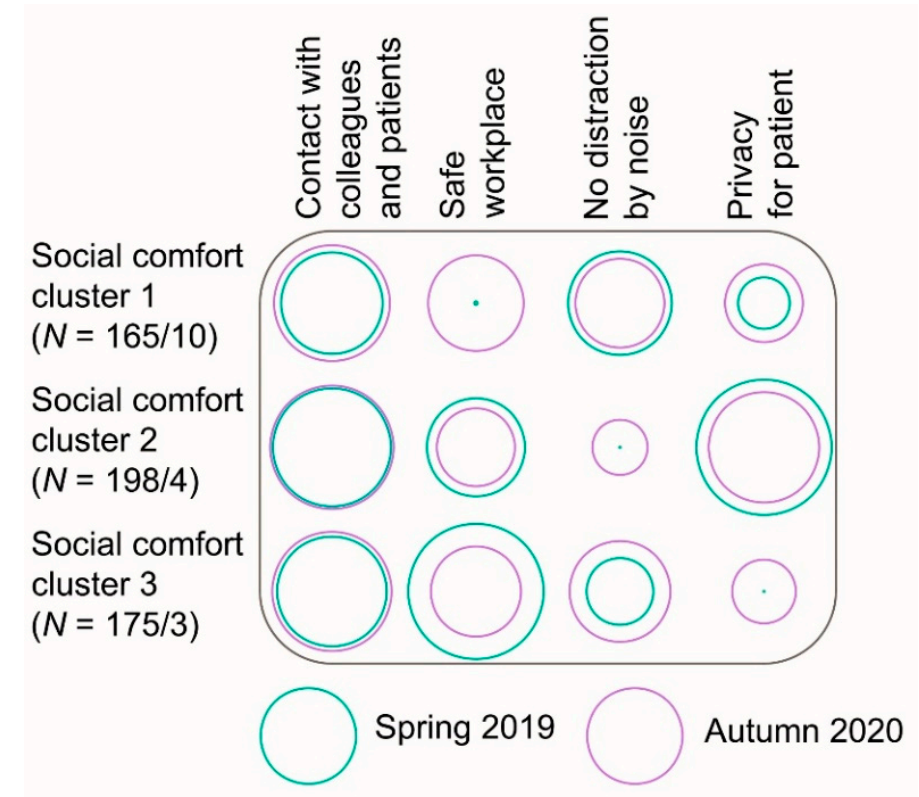

Figure 8. Proportion of preferences selected per social comfort cluster in 2019 and average rating of preferences in 2020 .

The number of cluster members from the survey of 2019 and interviews in 2020 are shown similarly as in Figure 7. The importance of most preferences for social comfort in 2020 did not vary from 2019. For example, contact with colleagues and patients was in all clusters for a large majority (ranging from 56\% to 76\%) important in 2019, and ranked similarly high (1.5 to 1.8 , of four aspects, with 1 for most important and 4 for least important) in 2020. The largest difference was the limited proportion $(0 \%)$ of outpatient workers who 
found a safe workplace important in 2019, while it was ranked intermediately (2.5) in 2020. The reason why those in cluster 1 regarded safety as important was different from those in clusters 2 and 3 . In cluster 1 safety was associated with building characteristics, such as a safe escape route or cleanliness, while safety was associated with verbal aggression of patients and the proximity of colleagues in clusters 2 and 3 . The reason why the outpatient workers found no distraction by noise important, varied partly. In cluster 1 concentration was necessary, while in all clusters noise from others, particularly telephone calls of colleagues, was perceived as annoying. This can be explained by the results from the survey, that indicated that those in cluster 1 perform generally more concentrated office work in comparison to those in cluster 2 and 3.

The reasons why the preferences for the privacy of patients and contact with others were important, did not vary between the clusters. Patient privacy was mainly important because of concerns about the audibility of personal information by other patients in the waiting room. Contact with colleagues and patients was perceived as important because of work satisfaction. Among the clusters, both collaboration with colleagues and interaction with patients contributed to work satisfaction.

Overall, it can be suggested that the importance of safety can vary between those in different social comfort clusters, while it is less likely that the reasons for the importance of the other social comfort aspects vary. The social comfort clusters seem generally robust, as the changes were limited between 2019 and 2020.

\subsection{Changes of Preferences}

The study shows that it is likely that the occupants' preferences can change due to contextual changes.

As choices for preferences are inevitably made in a context, it is difficult to distinguish contextual influences from preferences [51]. Preferences can be formed unconsciously by habituation and more consciously by reasoning [52]. The latter are more likely to change due to contextual cues $[51,53]$. A study that used neuroimaging data, showed that physiological reactions, representing the perceived importance of preferences, can strengthen after selection [54]. Hoeffler and Ariely (1999) suggested that a strong experience is more likely to form a stable preference, compared to a flawed experience [55]. The present study showed that the main preferences for daylight, noise, privacy for patients, and safety were more likely to change than the other IEQ and social comfort aspects. Future study is needed to indicate whether there are differences between comfort aspects in the strength of the experiences.

\subsection{IEQ in Relation to Changes Due to the COVID-19 Pandemic}

The present study shows that the influence and interrelations of physical characteristics, work, and personal aspects with comfort preferences are complex. For example, while the needs for control of natural ventilation and for sufficient fresh air, due to worries about infection risk, were expressed by seven participants, indoor air-related aspects were most important for three participants. Their main preference for indoor air-related aspects had not been altered since 2019. A possible cause is that some outpatient workers found that other IEQ-aspects affected their work performance more negatively if these were not met. The participants pointed out that opening windows influenced also thermal comfort, while opening doors influenced annoyance by noise.

However, the concern of the outpatient staff about indoor air quality as a possible risk factor for health and infection is not new. In previous studies, hospital staff regarded indoor air quality as among the top three most important aspects [26,56]. Furthermore, evidence of the possible transmission of SARS-CoV-2 through (small) airborne particles is growing [57]. For example, a study in the isolation wards of intensive care determined contamination with the SARS-CoV-2 virus on surfaces at the nursing station and in the indoor air [58]. The ventilation rate in the isolation wards was low, while tracheal intubation that may increase the concentration of airborne virus-carrying particles had been performed the day 
before data collection. Increased ventilation rate is one of the measures that can contribute to a lower concentration of airborne virus-carrying particles. Customization of mechanical ventilation systems and control of air supply through opening windows were among the measures recommended by Morawska et al. (2020) [59], to reduce the risk of the spread of the SARS-CoV-2 virus.

\subsection{Social Comfort in Relation to Changes Due to the COVID-19 Pandemic}

The experience of impoverished interaction, due to increased digital care, can be explained by the multi-sensory characteristics of face-to-face interaction. Similarly, the beneficial effects of face-to-face interaction for collaboration were identified in previous studies [60]. For example, a comparative study on the difference between video and face-toface meetings of physicians found less informal exchange and limited willingness to discuss diagnostic problems through video calls as compared with face-to-face meetings [61].

There is a gap in empirical studies on the perception by caregivers of digital care during the COVID-19 pandemic $[62,63]$. However, previous comments on the rapid shift to digital care during the pandemic suggested changes in social interaction through video calls in comparison to face-to-face meetings. For example, Romanick-Schmiedl and Ragu (2020) [64] suggested that face-to-face interaction between patient and caregiver contributed to a trusting relationship, which is essential for the health care process. Furthermore, cues for correct diagnosis of the patient, such as observation of trembling fingers, could be missed in virtual contact. Rosen et al. (2020) [65] suggested that contact with patients might improve through digital care because the patients are comfortable in their own homes. Notwithstanding the benefits of digital care, in terms of infection risk, expenses, travel, and time, the perception of social comfort can be influenced negatively by the shift from face-to-face meetings to digital care.

\subsection{Methodological Considerations}

The lens that was specifically chosen for this study provided insight into changes due to the COVID-19 pandemic and other factors. Other lenses such as the experience of basic and linear factors derived from Kano's model for satisfaction [66] or different adaptive strategies to achieve comfort $[14,15]$, could have allowed us to analyse the preferences. However, because it was unknown whether the outpatient areas were changed due to the COVID-19 pandemic, it seemed most appropriate to form a data structure of the changes, that the participants related to the pandemic.

In the present study, a ranking was used because this method is most suitable to assess a hierarchy of preferences, while rating scales are most suitable to assess appraisal [67]. One of the benefits of ranking preferences instead of rating them is to overcome differences in the assessment between persons [68]. Therefore, the ranking was also used for the preferences (three most important aspects) and the rating for satisfaction with comfort (scale 1 to 7 ) in the survey [25]. Subsequently, the clusters were produced with the categorical values for preferences (binary data) and components of comfort (continuous data from principal component analysis) with two-step cluster analysis. This technique is suitable for both types of data [24]. The present study shows that differentiation of preferences can be illogical for outpatient workers because they find some or all comfort aspects evenly important. Furthermore, interrelations were perceived between the comfort aspects. Therefore, future research is needed to compare the consistency of ranking and rating for comfort preferences.

\subsection{Limitations}

One of the limitations of this study can be participation bias. To limit this bias, participants from all clusters, differing in preferences and comfort, were represented in this study. Therefore, it was expected that the participants would constitute a group of outpatient workers with different main preferences and satisfaction with comfort. Although the preferences of some participants had changed since 2019, the main preferences of the total sample differed also in the present study. 
Another limitation is that some outpatient workers found the ranking of comfort aspects to be illogical. The perceived lack of logic to rank comfort aspects might have influenced the identification of preferences. For example, participants in cluster 3 regarded differentiation of preferences as illogical, while their preference for daylight changed. Furthermore, careful consideration is needed for the generalization of the results, mainly of IEQ clusters 2, 3, 4, because of the low number of participants. Also, transfer of the findings to other occupant groups (such as patients) or departments (such as inpatient areas) needs careful consideration, because the occupant needs can vary due to differences in building characteristics, duration of stay, activities, etc. [20,21].

\subsection{Recommendations}

This study shows that the main preferences of the outpatient workers can vary. Based on the results it can be suggested that manual control of IEQ aspects is one of the solutions to improve the comfort of individuals. A previous study on thermal comfort of hospital workers at inpatient areas recommended hospital organizations accommodate different set points, related to zones that varied in occupancy and activities [69]. However, as the preferences of individuals that work together in the same area can vary, additional solutions are needed. Other solutions that hospital organizations can accommodate for are e.g., adjusted clothing (uniforms), use of other rooms, or compensation during breaks. In line with compensation during breaks, Lembo et al. (2021) suggested reducing the duration of work shifts during the COVID-19 pandemic because of thermal discomfort of the hospital workers that used personal protective equipment [70]. Also, measures to increase the ventilation rate may improve comfort and reduce worries of outpatient workers. Ventilation could be improved and reduce the risk of the spread of the SARS$\mathrm{CoV}-2$ virus through the opening of windows, air filtration, disinfection, and accurate operation of the HVAC systems [59,71]. Jain et al. (2021) [72] addressed the importance of a correct balance between the occupants' comfort and energy use of HVAC systems in hospitals. They suggested developing strategies for measurement and control of IEQ including measurement of the system performance. Furthermore, as the intelligibility of patients may decrease due to splash guards and facial masks, additional acoustic measures are needed during an epidemic. Possible solutions are reconsideration of splash guards, application of extra sound absorbing materials and reduction of environmental noises. This is important because a poor acoustic environment and reduced privacy may increase the incidence of burn out of healthcare workers [73], a risk that increased during the COVID-19 pandemic [74]. Furthermore, it can be suggested that places that accommodate safely for face-to-face contact with hospital workers and patients are needed for medical and informal informal exchange. Places for interaction with others may also decrease the healthcare workers' work pressure [75]. To support social distancing and face-to-face interaction, the occupant density of rooms, areas, and corridors might be considered [71].

\section{Conclusions}

In this study, the preferences for IEQ and social comfort of the outpatient workers during the COVID-19 pandemic were investigated and compared to preferences for IEQ and social comfort identified before the pandemic started. The perceived changes of adaptations to reduce the infection risk of the SARS-CoV2 virus in hospitals were summarized. The outpatient workers had worries about the indoor air quality, were annoyed by a decreased speech intelligibility with patients, impoverished interaction, increased difficulties with patient privacy, and by their threatening behaviour. The study allowed us to compare preferences for IEQ and for social comfort with the interviewees' preferences that were identified in a survey before the COVID-19 pandemic started. The results from the previous study identified six clusters for IEQ and three clusters for social comfort that were distinguished by their preferences and comfort. The present study showed that the reason why IEQ aspects are important varied between the clusters, while the variation for social comfort aspects was limited. 
For some of the outpatient workers, differentiation was illogical due to interrelations and the equal importance of the comfort aspects. This was the case with IEQ as well as with social comfort.

Finally, the study implies that the occupants' preferences for IEQ and social comfort can change over time, due to contextual or personal changes. Therefore, it can be suggested that further development of occupant profiles that might be used in the programmatic or design phase of renovation and newly built outpatient areas is needed.

Author Contributions: Conceptualization, A.E., M.A.O., and P.M.B., methodology, A.E., M.A.O.; software, A.E.; validation, A.E., M.A.O., and P.M.B.; formal analysis, A.E.; investigation, A.E.; resources, A.E.; data curation, A.E.; writing-original draft preparation, A.E.; writing-review and editing, M.A.O. and P.M.B.; visualization, A.E.; supervision, P.M.B.; project administration, P.M.B.; funding acquisition, A.E. All authors have read and agreed to the published version of the manuscript.

Funding: This work was funded by DAIKIN NEDERLAND and EGM as part of the PhD project "user experiences and preferences in health care centres" at the Delft University of Technology under the chair of indoor environment at the Faculty of Architecture and the Built Environment.

Institutional Review Board Statement: The study was conducted according to the guidelines of the Declaration of Helsinki, and approved by the Institutional Review Board (or Ethics Committee) of DELFT UNIVERSITY OF TECHNOLOGY (5 October 2018).

Informed Consent Statement: Informed consent was obtained from all subjects involved in the study.

Data Availability Statement: More information on the data presented in this study is available on request from the corresponding author. The data are not publicly available due to restrictions regarding the privacy of the participants.

Conflicts of Interest: The authors declare no conflict of interest. The funders had no role in the design of the study; in the collection, analyses, or interpretation of data; in the writing of the manuscript; or in the decision to publish the results.

\section{Appendix A}

Quotation 1 (Dutch): “En ik vind dat wel een lastig iets, nu met die Covid natuurlijk ook. Want er was toen nog onderzoek geweest dat het zolang blijft hangen in liften. En dan denk ik: "Hoelang blijft het hier in mijn kamer hangen?" Ik kan niet even een raam openzetten of zoiets. Of de ventilatie aanzetten. Want dat is er niet!" (Verpleegkundige, vrouw).

Quotation 1 (British English): "And I find it annoying too now, with the COVID-19. Because there was a study saying that it lingers in the air for a long time in the elevators. So, I think: how long does it linger in my room? I can't open a window or anything. Or turn on the ventilation. Because we don't have it!" (Nurse, female).

Quotation 3 (Dutch): "Geen geluidsoverlast zou wel fijn zijn. Dat vind ik wel belangrijk. Juist omdat je de patiënt nu zo moeilijk kan verstaan. Ik merk nu, doordat die schermen daar hangen en mensen mondkapjes op hebben, dat ik op dit moment daar meer problemen mee heb dan dat ik voor coronatijd zou hebben." (Receptie medewerker, vrouw).

Quotation 2 (Dutch): "Ik houd van een beetje lucht, he. En nu gaan ze [de collega's] er [raam openzetten] weer in mee he, omdat ze weten dat het met de corona beter is. Als je met zijn allen in een ruimte zit natuurlijk. We kunnen dat redelijk dealen. 's Ochtends als ik binnenkom, zet ik hem open en als ze het zat zijn dat gaat hij dicht. Zo hebben we het met elkaar afgesproken en dat doen we ook met de lunch. Dan gaat hij ook een half uurtje open en dan gaat hij ook weer dicht." (Administratief medewerker, vrouw).

Quotation 2 (British English): "I like a little bit of air. And now they [the colleagues] also go ahead with it [opening windows], because they know that during coronavirus it is better to do it, especially if you're all together in a room. We do it pretty well. In the morning when I arrive, I open the windows, and when they've had enough of it, we shut them. That's what we agreed, and we also do it at lunchtime. We open them for half an hour and then shut them again." (Administrative worker, female). 
Quotation 3 (British English): "If there weren't any noise annoyances, it would be nice. I think that's pretty important. Exactly because now, you can't understand the patients well. I notice that now, with the hanging splash guards and people wearing facial masks, that I have more problems with that than I had before the coronavirus." (Reception desk worker, female).

Quotation 4 (Dutch): "Ik merk gewoon dat ik daar, en misschien heeft dat ook wel met de leeftijd te maken, vroeger had ik daar minder last van. Maar ik kan echt wel merken dat ik behoefte heb aan daglicht. En ik heb van de zomer zelfs momenten gehad als ik van mijn werk kwam zei ik tegen mijn man: "ik ga nog even in de tuin zitten, want ik wil nog even een beetje zonlicht opvangen." Dat ik echt dacht: "ik moet heel even naar buiten" [lachen]." (Diagnostisch medewerker, vrouw).

Quotation 4 (British English): "I've noticed that I used to suffer less with that, but that may be because of my age. But I really see that I do need daylight. I remember from the summer, there were times I came back from work and told my husband: "I'll be out in the garden for a while, I'd like to get some sunlight." I was actually thinking: "I do have to go out" [laughs]." (Diagnostic researcher, female).

Quotation 5 (Dutch): “Als je vraagt: [..] "Heeft u alles begrepen?" "Ja." Maar dat is niet altijd zo. Dan kun je nog wel eens merken van: “Oh, er zit daar een stukje wat nog niet begrepen wordt." En daar kun je dan [..] op reageren. Maar dat is wel weggevallen." (Receptie medewerker, vrouw).

Quotation 5 (British English): "When you ask: [ ... ] "Is everything clear so far?"; "yes". But they don't always say yes. So, you can sometimes notice: "oh, they still don't understand something". So that's when you can say something more. But that doesn't happen anymore." (Reception desk worker, female).

Quotation 6 (Dutch): "En ja dat lichamelijk onderzoek is wel iets dat je mist met de telefonische of de uh videoconsulten. [..] de opbrengst is niet altijd heel evident veel. Maar het is wel dat je iets kunt zien. Dat iemand zegt:" Mijn maag doet pijn." En dan met lichamelijk onderzoek dan wijzen ze hun onderbuik bijvoorbeeld aan. Dus dat je op die manier extra informatie kunt vergaren en uh [..], ik heb zelf het idee dat de aandacht die je besteed bij lichamelijk onderzoek uh is dat het, patiënten zich ook serieus genomen voelen." (Physician assistent, vrouw).

Quotation 6 (British English): "And yes, the physical check-up is something you miss during phone or video consultations [..] the output isn't always that evident. But it is something that you can see. If someone is telling you "My stomach hurts"; with a physical check-up they'll point at their lower abdomen, for example. So, you get some extra information and [uh], I actually feel that the attention you give them during a physical check-up makes them feel that they are being taken seriously." (Physician assistant, female).

Quotation 7 (Dutch): "Je staat alles te bespreken, je moet een geboortedatum vragen, je moet de huisarts vragen, de patiënten moeten het hard zeggen, nu nog harder, en diegenen in de wachtkamer kunnen alles horen en volgen. Dus er is niet heel veel privacy. Ik vind het persoonlijk vind ik dat vervelend. Want ja je hebt het toch in mijn geval over kanker en ja iedereen weet wel waarom je daar zit maar dat hoef je toch niet zo aan de grote klok te hangen [...]. Dat komt door die schermen, maar ook die mondkapjes ook, he. Anders kon je nog een beetje aan de mond zien wat ze zeiden. Maar dat kan ook niet meer." (Receptie medewerker, vrouw).

Quotation 7 (British English): "You discuss everything, you have to ask them their birthdate, you have to ask the general practitioner, the patients already had to be loud, but now even louder, and the others in the waiting room can overhear and follow everything. So, there isn't that much privacy. I personally find it disturbing. Because for example, in my case, you'll be talking about cancer, and so everyone knows why you are there, but it doesn't need to be that obvious. [..] All of this is because of the splash guards but also the facial masks. Otherwise, you could still see their mouths and see what they were telling you. But that's not possible anymore." (Reception worker, female). 


\section{Appendix B}

Table A1. Categories, subcategories, and second order codes.

\begin{tabular}{|c|c|c|}
\hline Category & Subcategory & Second Order Codes \\
\hline \multirow[t]{9}{*}{ Organizational adaptations } & Capacity care & $\begin{array}{l}\text { Reduction capacity care during first wave of the } \\
\text { pandemic (7) }\end{array}$ \\
\hline & & Recent capacity care normal (4) \\
\hline & & Capacity care not reduced during first wave (2) \\
\hline & & Waiting list for patients after first wave (3) \\
\hline & Number of persons in hospital building & Number of workplaces reduced (4) \\
\hline & & Number of visitors reduced (4) \\
\hline & & Number of patients reduced (3) \\
\hline & & Working partly from home (5) \\
\hline & & Spread staff among locations (2) \\
\hline \multirow[t]{11}{*}{ Adaptations work methods } & Corona care & Determine corona policy (1) \\
\hline & & Buddy corona care (2) \\
\hline & & Perform corona tests in triage tent (2) \\
\hline & Digital care & Digital meeting $(1)$ \\
\hline & & Digital consultation (4) \\
\hline & & Prepare digital consultations (6) \\
\hline & Face-to-face care & Face-to-face consultation when urgent (3) \\
\hline & & Physical examination when urgent (3) \\
\hline & & Decreased medical acts (2) \\
\hline & & Adjusted workflow (2) \\
\hline & & Increased disinfecting acts (2) \\
\hline \multirow[t]{8}{*}{ Physical adaptations } & Room & Seating in waiting room reduced (3) \\
\hline & & Stanchions in front of reception desk (5) \\
\hline & & Amount of stuff reduced (1) \\
\hline & & Location furniture adapted (3) \\
\hline & & Splash guard installed (2) \\
\hline & Protective clothing & Use of facial mask \\
\hline & & Use of facial shield \\
\hline & & Protective suit, glasses, and gloves (1) \\
\hline \multirow[t]{14}{*}{ Experience of changes } & Work pressure & Increased work pressure (8) \\
\hline & & Unchanged work pressure (4) \\
\hline & & Increased work pressure during the first wave (4) \\
\hline & & Suffering from Burn-out (1) \\
\hline & & Stressed feelings (2) \\
\hline & Satisfaction with work & Adjusted to new work method (3) \\
\hline & & Annoyed by extra administration (4) \\
\hline & & Worries about quality patientcare (3) \\
\hline & & Worries about infection (4) \\
\hline & & Satisfied with organization (1) \\
\hline & & Unsafe feelings because of dirt and dust (1) \\
\hline & Social comfort & Social distancing difficult (6) \\
\hline & & Missing face-to-face contact (8) \\
\hline & & Preferred to see facial expression (3) \\
\hline
\end{tabular}


Table A1. Cont.

\begin{tabular}{|c|c|c|}
\hline \multirow[t]{11}{*}{ Category } & Subcategory & Second Order Codes \\
\hline & & Increased privacy (1) \\
\hline & & Less annoyance by aggression (1) \\
\hline & & Annoyance by aggression (4) \\
\hline & Indoor environment & Missing control of ventilation (4) \\
\hline & & $\begin{array}{l}\text { Decreased intelligibility through facial mask or } \\
\text { splashguard (3) }\end{array}$ \\
\hline & & Preferred natural ventilation (3) \\
\hline & & Decreased discussion about control of temperature (1) \\
\hline & & Breathing difficulties through facemask (1) \\
\hline & & Protective suit too hot (1) \\
\hline & & Facial shield reflects light in screen (1) \\
\hline
\end{tabular}

$(\mathrm{x})=$ number of participants.

\section{References}

1. Barker, R. 2030-The Future of Medicine, Avoiding a Medical Meltdown; Oxford University Press Inc.: New York, NY, USA, 2011; p. 118. ISBN 978-0-19-960066-3.

2. CBS. Werknemers in de Zorg en Welzijn; Arbeidsomstandigheden. 2019. Available online: https://azwstatline.cbs.nl/\#/AZW / $\mathrm{nl} /$ dataset/24069NED/table?ts=1578064277911 (accessed on 1 March 2020).

3. Shader, K.; Broome, M.E.; Broome, C.D.; West, M.E.; Nash, M. Factors Influencing Satisfaction and Anticipated Turnover for Nurses in an Academic Medical Center. JONA J. Nurs. Adm. 2001, 31, 210-216. [CrossRef]

4. Grunfeld, E.; Whelan, T.J.; Zitzelsberger, L.; Willan, A.R.; Montesanto, B.; Evans, W.K. Cancer care workers in Ontario: Prev-alence of burnout, job stress and job satisfaction. Can. Med. Assoc. J. 2000, 163, 166-169.

5. McVicar, A. Workplace stress in nursing: A literature review. J. Adv. Nurs. 2003, 44, 633-642. [CrossRef] [PubMed]

6. Vischer, J.C. The effects of the physical environment on job performance: Towards a theoretical model of workspace stress. Stress Health 2007, 23, 175-184. [CrossRef]

7. Applebaum, D.; Fowler, S.; Fiedler, N.; Osinubi, O.; Robson, M. The Impact of Environmental Factors on Nursing Stress, Job Satisfaction, and Turnover Intention. JONA J. Nurs. Adm. 2010, 40, 323-328. [CrossRef] [PubMed]

8. Alimoglu, M.K.; Donmez, L. Daylight exposure and the other predictors of burnout among nurses in a University Hospital. Int. J. Nurs. Stud. 2005, 42, 549-555. [CrossRef]

9. Hashiguchi, N.; Hirakawa, M.; Tochihara, Y.; Kaji, Y.; Karaki, C. Thermal Environment and Subjective Responses of Patients and Staff in a Hospital during Winter. J. Physiol. Anthropol. Appl. Hum. Sci. 2005, 24, 111-115. [CrossRef]

10. Eijkelenboom, A.; Blok, G.A. Evaluation of design interventions for hospitality and privacy at inpatient wards. In Proceedings of the ARCH 2019, Trondheim, Norway, 12-14 June 2019; SINTEF Academic Press: Trondheim, Norway.

11. Eijkelenboom, A.; Blok, G.A.; Bluyssen, P.M. Comfort and satisfaction of patients, visitors and staff with patient rooms at inpatient wards, a pilot study. In Proceedings of the CLIMA 2019, E3S Web Conference, Bucharest, Romania, 26-29 May 2019.

12. Tähtinen, K.; Remes, J.; Karvala, K.; Salmi, K.; Lahtinen, M.; Reijula, K. Perceived indoor air quality and psychosocial work environment in office, school and health care environments in Finland. Int. J. Occup. Med. Environ. Health 2020, 33, 479-495. [CrossRef]

13. Hellgren, U.-M.; Reijula, K. Indoor-air-related complaints and symptoms among hospital workers. SJWEH Suppl. 2006, 2, 47-49.

14. Shin, J.-H. Toward a theory of environmental satisfaction and human comfort: A process-oriented and contextually sensitive theoretical framework. J. Environ. Psychol. 2016, 45, 11-21. [CrossRef]

15. Cole, R.J.; Robinson, J.; Brown, Z.; O'Shea, M. Re-contextualizing the notion of comfort. Build. Res. Inf. 2008, 36, 323-336. [CrossRef]

16. Willems, S.; Saelens, D.; Heylighen, A. Comfort requirements versus lived experience: Combining different research approaches to indoor environmental quality. Arch. Sci. Rev. 2020, 63, 316-324. [CrossRef]

17. Donetto, S.; Penfold, C.; Anderson, J.; Robert, G.; Maben, J. Nursing work and sensory experiences of hospital design: A before and after qualitative study following a move to all-single room inpatient accommodation. Health Place 2017, 46, 121-129. [CrossRef] [PubMed]

18. Pattison, H.M.; E Robertson, C. The effect of ward design on the well-being of post-operative patients. J. Adv. Nurs. 1996, 23, 820-826. [CrossRef] [PubMed]

19. Dean, M.; Gill, R.; Barbour, J.B. “Let's Sit Forward”: Investigating Interprofessional Communication, Collaboration, Professional Roles, and Physical Space at EmergiCare. Health Commun. 2016, 31, 1506-1516. [CrossRef] [PubMed]

20. Rashid, M.; Zimring, C. A Review of the Empirical Literature on the Relationships Between Indoor Environment and Stress in Health Care and Office Settings. Environ. Behav. 2008, 40, 151-190. [CrossRef] 
21. Eijkelenboom, A.; Bluyssen, P.M. Comfort and health of patients and staff, related to the physical environment of different departments in hospitals: A literature review. Intell. Build. Int. 2019. [CrossRef]

22. Eijkelenboom, A.; Kim, D.H.; Bluyssen, P.M. First results of self-reported health and comfort of staff in outpatient areas of hospitals in the Netherlands. Build. Environ. 2020, 177, 106871. [CrossRef]

23. Bluyssen, P.M. Towards an integrated analysis of the indoor environmental factors and its effects on occupants. Intell. Build. Int. 2019, 12, 199-207. [CrossRef]

24. Tkaczynski, A. Segmentation Using Two-Step Cluster Analysis. In Segmentation in Social Marketing: Process, Methods and Ap-plication; Dietrich, T., Rundle-Thiele, S., Kubacki, K., Eds.; Springer: Singapore, 2017; pp. 109-125. ISBN 978-981-10-1835-0.

25. Eijkelenboom, A.; Bluyssen, P.M. Profiling outpatient staff based on their self-reported comfort and preferences of indoor environmental quality and social comfort in six hospitals. Build. Environ. 2020, 184, 107220. [CrossRef]

26. Mourshed, M.; Zhao, Y. Healthcare providers' perception of design factors related to physical environments in hospitals. J. Environ. Psychol. 2012, 32, 362-370. [CrossRef]

27. Sadatsafavi, H.; Walewski, J.; Shepley, M.M. Factors influencing evaluation of patient areas, work spaces, and staff areas by healthcare professionals. Indoor Built Environ. 2015, 24, 439-456. [CrossRef]

28. Karjalainen, S.; Koistinen, O. User problems with individual temperature control in offices. Build. Environ. 2007, 42, 2880-2887. [CrossRef]

29. Healey, K.; Webster-Mannison, M. Exploring the influence of qualitative factors on the thermal comfort of office occupants. Arch Sci. Rev. 2012, 55, 169-175. [CrossRef]

30. Van Hoof, J.; Bennetts, H.; Hansen, A.; Kazak, J.K.; Soebarto, V. The Living Environment and Thermal Behaviours of Older South Australians: A Multi-Focus Group Study. Int. J. Environ. Res. Public Health 2019, 16, 935. [CrossRef] [PubMed]

31. Eon, C.; Morrison, G.M.; Byrne, J. Unraveling everyday heating practices in residential homes. Energy Procedia 2017, 121, 198-205. [CrossRef]

32. World Health Organization. Rolling Updates on Coronavirus Disease (COVID-19). 2019. Available online: https:/ /www.who. int/emergencies/diseases/novel-coronavirus-2019/events-as-they-happen (accessed on 21 March 2021).

33. McAlonan, G.M.; Lee, A.M.; Cheung, V.; Cheung, C.; Tsang, K.W.; Sham, P.C.; Chua, S.E.; Wong, J.G. Immediate and Sustained Psychological Impact of an Emerging Infectious Disease Outbreak on Health Care Workers. Can. J. Psychiatry 2007, 52, 241-247. [CrossRef]

34. Belfroid, E.; van Steenbergen, J.; Timen, A.; Ellerbroek, P.; Huis, A.; Hulscher, M. Preparedness and the importance of meeting the needs of healthcare workers: A qualitative study on Ebola. J. Hosp. Infect. 2018, 98, 212-218. [CrossRef] [PubMed]

35. Tam, C.W.C.; Pang, E.P.F.; Lam, L.C.W.; Chiu, H.F.K. Severe acute respiratory syndrome (SARS) in Hong Kong in 2003: Stress and psychological impact among frontline healthcare workers. Psychol. Med. 2004, 34, 1197-1204. [CrossRef] [PubMed]

36. Chew, N.W.S.; Lee, G.K.H.; Tan, B.Y.Q.; Jing, M.; Goh, Y.; Ngiam, N.J.H.; Yeo, L.L.L.; Ahmad, A.; Khan, F.A.; Napolean, G.; et al. A multinational, multicentre study on the psychological outcomes and associated physical symptoms amongst healthcare workers during COVID-19 outbreak. Brain Behav. Immun. 2020, 88, 559-565. [CrossRef]

37. Aalto, L.; Lappalainen, S.; Salonen, H.; Reijula, K. Usability evaluation (IEQ survey) in hospital buildings. Int. J. Work. Health Manag. 2017, 10, 265-282. [CrossRef]

38. Amaratunga, D.; Baldry, D.; Sarshar, M.; Newton, R. Quantitative and qualitative research in the built environment: Application of "mixed" research approach. Work. Study 2002, 51, 17-31. [CrossRef]

39. Creswell, J.W. Research Design Qualitative, Quantitative, And Mixed Methods Approaches, 4th ed.; SAGE: Thousand Oaks, CA, USA, 2014; ISBN 978-4129-6556-9.

40. Johnson, R.B.; Onwuegbuzie, A. Mixed Methods Research: A Research Paradigm Whose Time Has Come. Educ. Res. 2004, 33, 14-26. [CrossRef]

41. Critical Appraisal Skills Programme. CASP. 2018. Available online: https://casp-uk.net/casp-tools-checklists/ (accessed on 1 October 2020).

42. Wilhoit, E.D. Photo and Video Methods in Organizational and Managerial Communication Research. Manag. Commun. Q. 2017, 31, 447-466. [CrossRef]

43. Van Hoof, J.; Verbeek, H.; Janssen, B.M.; Eijkelenboom, A.; Molony, S.L.; Felix, E.; Nieboer, K.A.; Zwerts-Verhelst, E.L.M.; Sijstermans, J.J.W.M.; Wouters, E.J.M. A three perspective study of the sense of home of nursing home residents: The views of residents, care professionals and relatives. BMC Geriatr. 2016, 16, 15. [CrossRef] [PubMed]

44. Annemans, M.; Van Audenhove, C.; Vermolen, H.; Heylighen, A. Hospital Reality from a Lying Perspective: Exploring a Sensory Research Approach. In Designing Inclusive Systems; Langdon, P., Clarkson, J., Robinson, P., Lazar, J., Heylighen, A., Eds.; Springer: London, UK, 2012; pp. 3-12. [CrossRef]

45. Barriball, K.L.; While, A. Collecting data using a semi-structured interview: A discussion paper. J. Adv. Nurs. 1994, 19, 328-335. [CrossRef] [PubMed]

46. Kallio, H.; Pietilä, A.-M.; Johnson, M.; Kangasniemi, M. Systematic methodological review: Developing a framework for a qualitative semi-structured interview guide. J. Adv. Nurs. 2016, 72, 2954-2965. [CrossRef]

47. Gioia, D.A.; Corley, K.G.; Hamilton, A.L. Seeking Qualitative Rigor in Inductive Research: Notes on the Gioia Methodology. Organizational Research. Organ. Res. Methods 2013, 16, 15-31. [CrossRef] 
48. Eldh, A.C.; Årestedt, L.; Berterö, C. Quotations in Qualitative Studies: Reflections on Constituents, Custom, and Purpose. Int. J. Qual. Methods 2020, 19. [CrossRef]

49. Anderson, C. Presenting and Evaluating Qualitative Research. Am. J. Pharm. Educ. 2010, 74, 141. [CrossRef]

50. Bailey, D.M.; Jackson, J.M. Qualitative Data Analysis: Challenges and Dilemmas Related to Theory and Method. Am. J. Occup. Ther. 2003, 57, 57-65. [CrossRef] [PubMed]

51. Amir, O.; Levav, J. Choice Construction versus Preference Construction: The Instability of Preferences Learned in Context. J. Mark. Res. 2008, 45, 145-158. [CrossRef]

52. Zajonc, R.B.; Markus, H. Affective and Cognitive Factors in Preferences. J. Consum. Res. 1982, 9, 123-131. [CrossRef]

53. Tversky, A.; Simonson, I. Context-Dependent Preferences. Manag. Sci. 1993, 39, 1179-1189. [CrossRef]

54. Sharot, T.; De Martino, B.; Dolan, R.J. How Choice Reveals and Shapes Expected Hedonic Outcome. J. Neurosci. 2009, 29, 3760-3765. [CrossRef]

55. Hoeffler, S.; Ariely, D. Constructing Stable Preferences: A Look into Dimensions of Experience and Their Impact on Preference Stability. J. Consum. Psychol. 1999, 8, 113-139. [CrossRef]

56. Mroczek, J.; Mikitarian, G.; Vieira, E.K.; Rotarius, T. Hospital Design and Staff Perceptions. Health Care Manag. 2005, 24, 233-244. [CrossRef] [PubMed]

57. Tang, J.; Bahnfleth, W.; Bluyssen, P.; Buonanno, G.; Jimenez, J.; Kurnitski, J.; Li, Y.; Miller, S.; Sekhar, C.; Morawska, L.; et al. Dismantling myths on the airborne transmission of severe acute respiratory syndrome coronavirus-2 (SARS-CoV-2). J. Hosp. Infect. 2021, 110, 89-96. [CrossRef]

58. Jiang, Y.; Wang, H.; Chen, Y.; He, J.; Chen, L.; Liu, Y.; Hu, X.; Li, A.; Liu, S.; Zhang, P.; et al. Clinical Data on Hospital Environmental Hygiene Monitoring and Medical Staff Protection during the Coronavirus Disease 2019 Outbreak. medRxiv 2020. [CrossRef]

59. Morawska, L.; Tang, J.W.; Bahnfleth, W.; Bluyssen, P.M.; Boerstra, A.; Buonanno, G.; Cao, J.; Dancer, S.; Floto, A.; Franchimon, F.; et al. How can airborne transmission of COVID-19 indoors be minimised? Environ. Int. 2020, 142, 105832. [CrossRef]

60. Rashid, M. Hospital Design and Face to Face Interaction among Clinicians: A Theoretical Model. HERD Health Environ. Res. Des. J. 2009, 2, 62-84. [CrossRef] [PubMed]

61. Delaney, G.; Jacob, S.; Iedema, R.; Winters, M.; Barton, M. Comparison of face-to-face and videoconferenced multidisciplinary clinical meetings. Australas. Radiol. 2004, 48, 487-492. [CrossRef]

62. Crawford, A.; Serhal, E. Digital Health Equity and COVID-19: The Innovation Curve Cannot Reinforce the Social Gradient of Health. J. Med. Internet Res. 2020, 22, e19361. [CrossRef]

63. Doraiswamy, S.; Abraham, A.; Mamtani, R.; Cheema, S. Use of Telehealth During the COVID-19 Pandemic: Scoping Review. J. Med. Internet Res. 2020, 22, e24087. [CrossRef]

64. Romanick-Schmiedl, S.; Raghu, G. Telemedicine-Maintaining quality during times of transition. Nat. Rev. Dis. Prim. 2020, 6, 45. [CrossRef]

65. Rosen, C.B.; Joffe, S.; Kelz, R.R. COVID-19 Moves Medicine into a Virtual Space: A Paradigm Shift from Touch to Talk to Establish Trust. Ann. Surg. 2020, 272, e159-e160. [CrossRef]

66. Kim, J.; de Dear, R. Nonlinear relationships between individual IEQ factors and overall workspace satisfaction. Build. Environ. 2011, 49, 33-40. [CrossRef]

67. Harzing, A.-W.; Baldueza, J.; Barner-Rasmussen, W.; Barzantny, C.; Canabal, A.; Davila, A.; Espejo, A.; Ferreira, R.; Giroud, A.; Koester, K.; et al. Rating versus ranking: What is the best way to reduce response and language bias in cross-national research? Int. Bus. Rev. 2009, 18, 417-432. [CrossRef]

68. Yannakakis, G.N.; Martínez, H.P. Ratings are Overrated! Front. ICT 2015, 2. [CrossRef]

69. Derks, M.; Mishra, A.; Loomans, M.; Kort, H. Understanding thermal comfort perception of nurses in a hospital ward work environment. Build. Environ. 2018, 140, 119-127. [CrossRef]

70. Lembo, M.; Vedetta, C.; Moscato, U.; del Gaudio, M. Thermal discomfort in healthcare workers during the COVID-19 pandemic. Med. Lavoro 2021, 112, 123-129. [CrossRef]

71. Awada, M.; Becerik-Gerber, B.; Hoque, S.; O’Neill, Z.; Pedrielli, G.; Wen, J.; Wu, T. Ten questions concerning occupant health in buildings during normal operations and extreme events including the COVID-19 pandemic. Build. Environ. 2021, 188, 107480. [CrossRef]

72. Jain, N.; Burman, E.; Stamp, S.; Shrubsole, C.; Bunn, R.; Oberman, T.; Barrett, E.; Aletta, F.; Kang, J.; Raynham, P.; et al. Building Performance Evaluation of a New Hospital Building in the UK: Balancing Indoor Environmental Quality and Energy Performance. Atmosphere 2021, 12, 115. [CrossRef]

73. Lupo, R.; Lezzi, A.; Conte, L.; Santoro, P.; Carvello, M.; Artioli, G.; Calabrò, A.; Caldararo, C.; Botti, S.; Carriero, M.C. Work environment and related burnout levels: Survey among healthcare workers in two hospitals of Southern Italy: Work environment and related burnout levels among healthcare workers. Acta Biomed. 2021, 92 (Suppl. 2), e2021009. [CrossRef]

74. Shreffler, J.; Huecker, M.; Petrey, J. The Impact of COVID-19 on Healthcare Worker Wellness: A Scoping Review. West. J. Emerg. Med. 2020, 21, 1059-1066. [CrossRef]

75. Karanikola, P.; Andrea, V.; Tampakis, S.; Tsolakidou, A. Indoor and Outdoor Design in Healthcare Environments: The Employees' Views in the General University Hospital of Alexandroupolis, Greece. Environments 2020, 7, 61. [CrossRef] 